\title{
Kekuatan Tarik dan Lentur pada Material Komposit Berpenguat Serat Jelatang
}

\author{
I Gede Putu Agus Suryawan¹, NPG Suardana1), I Ketut Suarsana1), I Putu Lokantara1), \\ I Ketut Jaya Lagawa') \\ 1)Jurusan Teknik Mesin Universitas Udayana, Kampus Bukit Jimbaran Bali
}

Naskah diterima 13/02/2019; direvisi 08/04/2019; disetujui 23/04/2019

doi: https://doi.org/10.24843/JEM.2019.v12.i01.p02

\begin{abstract}
Abstrak
Material komposit telah dikembangkan sebagai material alternatif pengganti logam dan kayu. Komposit dari matrik epoksi dengan penguat serat alam sedang dikembangkan, karena serat sintetis sulit terurai secara alami. Komposit dengan penguat serat alam lebih ramah lingkungan. Tanaman jelatang (stinging nettle) merupakan tanaman yang memiliki serat pada kulit batang. Tanaman jelatang tumbuh di seluruh wilayah Indonesia yang beriklim sedang. Di Bali banyak tumbuh di daerah Pupuan-Tabanan. Sifat yang khusus dari serat jelatang adalah kuat dan ringan. Penelitian ini bertujuan untuk mengetahui kekuatan tarik dan lentur komposit epoksi dengan penguat serat jelatang dengan fraksi volume $10 \%, 15 \%$, dan $20 \%$ serat, perlakukan serat dengan $\mathrm{NaOH} 6 \%$ direndam selama 2 jam, panjang serat $5 \mathrm{~mm}$ dengan orientasi acak. Komposit dicetak dengan metode hand lay up. Hasil yang didapat dari penelitian ini adalah kekuatan tarik komposit mengalami kenaikan dengan bertambahnya fraksi serat. Nilai kekuatan lentur tertinggi didapatkan pada fraksi volume serat $20 \%$ sebesar 46,693 MPa.
\end{abstract}

Kata kunci: Komposit, epoksi, serat jelatang, kekuatan tarik, lentur

\begin{abstract}
Composite material has been developed as an alternative material, it is substitute for metal and wood. Composites from epoxy with natural fiber reinforcement are being developed, because synthetic fibers are difficult to decompose naturally. Composite with natural fiber reinforcement is more environmentally friendly. Stinging nettles are plants that have fiber on the bark. Nettle plants grow in sub-district of Indonesia with temperate climates. In Bali many grow in the Pupuan-Tabanan area. The special properties of nettle fibers is strong and light. This study aims to determine the tensile and flexural strength of epoxy composites reinforcement nettle fibers with a volume fraction of fibers $10 \%, 15 \%$, and $20 \%$, treatment fibers with $6 \% \mathrm{NaOH}$, soaked for 2 hours, $5 \mathrm{~mm}$ fiber length with random orientation. Composites are product using the hand lay up method. The results obtained from this study are that the composite tensile strength increases with rise fiber fraction. The highest flexural strength value was obtained at $20 \%$ fiber fraction of $46.693 \mathrm{MPa}$.
\end{abstract}

Keywords: Composite, epoxy, nettle fiber, tensile, flexural

\section{Pendahuluan}

Komposit dari matrik epoksi dan penguat serat jelatang sedang kembangkan menjadi bahan alternatif pengganti komposit sintetis dan logam. Hal ini dapat dilakukan karena sifat dari komposit serat jelatang yang kuat dan ringan. Jelatang merupakan tanaman yang memiliki serat pada kulit batang dan cocok untuk di budidayakan di Asia dan Indonesia. Jelatang tumbuh subur di Bali Indonesia khususnya daerah Pupuan. Tanaman jelatang ialah tanaman tahunan dapat hidup \pm 1 tahun. Tanaman jelatang membutuhkan tanah yang subur untuk dapat tumbuh dengan baik.

Penelitian oleh Edwin Bodros dan Christophe Baley, hasil spesifikasi teknik serat jelatang sangat potensial sebagai penguat material komposit. Spesifikasi teknik untuk serat jelatang adalah young's modulus $87( \pm 28) \mathrm{GPa}$, kekuatan tarik $1594( \pm 640)$ $\mathrm{MPa}$, regangan patah $2,11 \quad( \pm 0,81) \%$ dan diameter rata-rata 19,9 $( \pm 4,4) \mu \mathrm{m}$. [1]

Penelitian tentang poly lactic acid (PLA) diperkuat serat jelatang dengan perbandingan $20 \%, 30 \%$ dan $40 \%$ berat serat diperoleh kekuatan tarik material komposit masing-masing $45 \mathrm{MPa}, 59 \mathrm{MPa}$ dan 40
MPa. Sedangkan kekuatan tarik PLA tanpa serat adalah $52 \mathrm{Mpa}$. [2]

Serat jelatang sangat potensial dipergunakan untuk penguat material komposit, terlihat dari hasil penelitian yang dilakukan oleh beberapa penelitian. Diperlukan suatu penanganan khusus untuk memproduksi serat jelatang yang halus dan untuk mendapatkan kekuatan tarik serat yang tinggi. [3]

Penelitian ini membahas pengaruh fraksi volume serat $10 \%, 15 \%$, dan $20 \%$ pada serat jelatang sebagai penguat material komposit epoksi terhadap kekuatan tarik dan lentur. Batang jelatang dipanen dari daerah Tabanan, minimal tingginya $50 \mathrm{~cm}$. Batang jelatang yang dipanen dikeringkan dengan sinar matahari dan kemudian direndam dalam air untuk mempermudah mendapatkan seratnya. Serat diambil dengan decortication yaitu memisahkan serat dari kulit batang secara hati-hati dengan alat bantu sederhana dan tangan. 


\section{Metode Penelitian}

\subsection{Bahan}

Bahan untuk matrik adalah resin epoksi dan hardener dibeli secara daring melalui CV Subur Kimia Jaya Bandung. Batang jelatang (stinging nettle) dipanen dari daerah Pupuan Tabanan Bali. Air suling untuk mencuci serat. Bahan kimia $\mathrm{NaOH}$ untuk menghilangkan lignin pada serat. Gliserin agar material komposit tidak menempel pada cetakan.

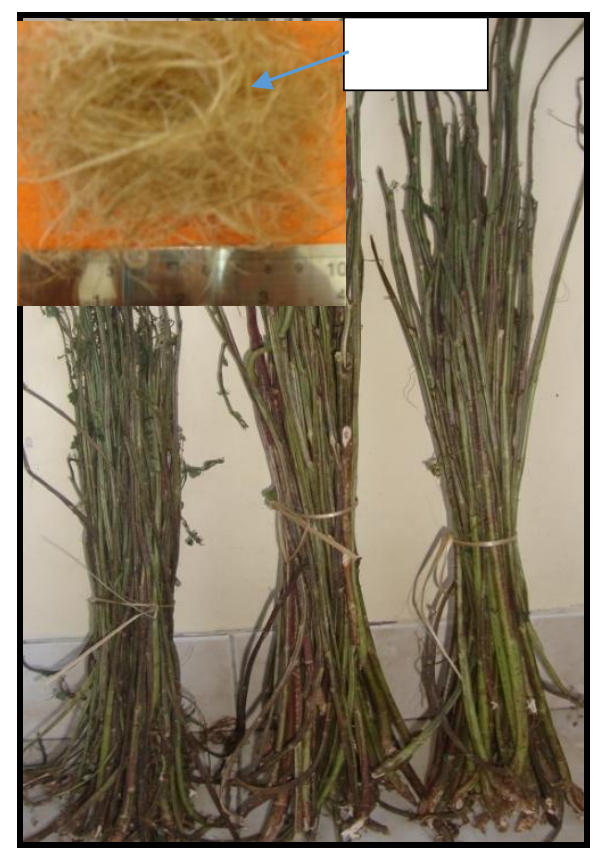

Gambar 1. Batang jelatang

\subsection{Alat Penelitian}

Timbangan dengan ketelitian $0,01 \mathrm{~g}$ digunakan untuk menimbang resin dan serat. Cetakan komposit terbuat dari kaca. Gelas ukur berfungsi menakar matrik. Alat ukur yang lain adalah jangka sorong, balok penekan, mesin potong digunakan untuk finishing. Pembuatan material dilakukan di Laboratorium Penomena Dasar Teknik Mesin Universitas Udayana. Pengujian kekuatan tarik dilakukan di Balai Besar Bahan dan Barang Teknik Bandung. Pengujian kekuatan lentur menggunakan alat uji universal testing machine di Laboratorium Bahan Teknik Universitas Gajah Mada. SEM dilakukan di Laboratorium Scaning Electron Microscope Departemen Teknik Mesin lantai 2 ruang D200 Kampus ITS Surabaya.

\subsection{Pencetakan Spesimen Komposit}

Adapun prosedur dalam pencetakan komposit antara lain:

a. Bahan dan peralatan disiapkan.

b. Serat jelatang direndam dalam $\mathrm{NaOH} 6 \%$ selama 2 jam lalu keringkan

c. Penguat dan pengikat disiapkan sesuai perhitungan dengan prosentase volume.

d. Cetakan disiapkan dan dibersihkan terlebih dahulu dengan kuas.

e. Bagian dalam cetakan komposit dioleskan gliserin secara tipis dan merata. f. Resin dan katalis dicampur dengan perbandingan katalis 1\% kedalam gelas ukur, diaduk hingga tercampur dengan merata.

g. Serat jelatang dimasukkan ke campuran resin dan katalis, diaduk hingga tercampur dengan merata.

h. Campuran serat dan resin dituang ke dalam cetakan, ratakan dan diberi tekanan menggunakan alat pengaduk sehingga penguat dan pengikat merata pada semua bagian cetakan.

i. Tutup cetakan menggunakan kaca lalu diberi tekanan, dengan maksud dapat mengurangi void atau rongga pada spesimen.

j. Spesimen komposit mengeras selama 8-12 jam.

k. Setelah kering atau mengeras, komposit dikeluarkan dari cetakan, hasil komposit diamati secara manual apakah void dan kelengkungan tidak melebihi dengan ketentuan.

I. Spesimen siap untuk diuji.

\subsection{Pengamatan bentuk fisik komposit}

Komposit sebagai spesimen uji dinyatakan homogen dan berhasil jika tidak patah, retak, cacat atau void yang mengumpul pada suatu tempat. Komposit yang berhasil dicetak diamati kelengkunganya, dengan meletakan lembaran komposit diatas lembaran kaca. Apabila terjadi kelengkungan, dapat digunakan apabila kelengkungan tidak lebih $2,5 \%$ dari panjang komposit.

\subsection{Pengujian Kekuatan Tarik Komposit}

Uji tarik (tensile test) adalah pengujian terhadap suatu material uji dengan cara dicengkram dan ditarik hingga material tersebut putus. Tujuan dari uji tarik ini adalah untuk mengetahui kekuatan tarik, elongation dan Modulus Young dari material.

Analisa data menggunakan kurva teganganregangan yang dibuat dari data tegangan-regangan secara longitudinal dari benda uji. Tegangan tarik dapat diperoleh dengan rumus :

$$
\sigma=\frac{P}{A_{0}}
$$

Dimana; $\sigma$ adalah tegangan tarik (MPa), $\mathrm{P}$ adalah beban $(\mathrm{N}), \mathrm{A}_{\circ}$ adalah luas penampang awal $\left(\mathrm{mm}^{2}\right)$.

Nilai regangan tarik diperoleh dari:

$$
\varepsilon=\frac{L-L_{0}}{L_{0}}
$$

Dimana; $\varepsilon$ adalah regangan tarik $(\mathrm{mm} / \mathrm{mm}), \mathrm{L}_{o}$ adalah panjang awal $(\mathrm{mm})$, L adalah panjang akhir $(\mathrm{mm})$.

Nilai Modulus Elastisitas diperoleh dari:

$$
E=\frac{\Delta \sigma}{\Delta \varepsilon}
$$

Dimana; E adalah elastisitas atau Modulus Young $(\mathrm{GPa}), \Delta \sigma$ adalah perbedaan tegangan di daerah elastis (MPa), $\Delta \varepsilon$ adalah perbedaan regangan di daerah elastis $(\mathrm{mm} / \mathrm{mm})$.

Pengujian tarik untuk mengetahui besarnya kekuatan tarik. Spesimen pengujian tarik di bentuk 
standar ASTM D3039/D3039M yang ditunjukkan pada gambar 2.

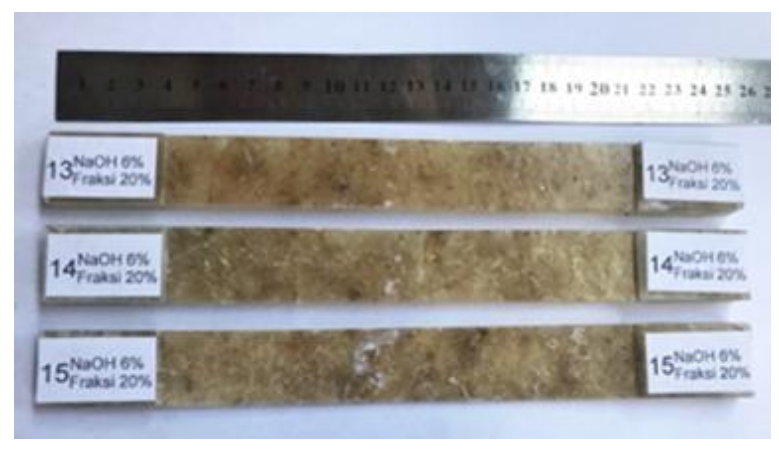

Gambar 2. Spesimen uji tarik

\subsection{Pengujian Kekuatan Lentur Komposit}

Pengujian kekuatan lentur menggunakan standar ASTM D790-03 dengan metode 3-point bending. Dimana spesimen diletakkan pada dua tumpuan dengan jarak yang telah ditentukan, kemudian diberikan beban di tengah tumpuan tersebut dengan pembebanan konstan.

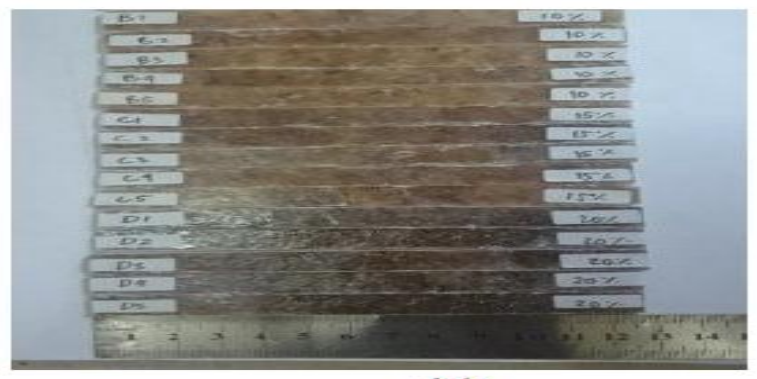

Gambar 3. Spesimen uji lentur

Perhitungan kekuatan lentur mengacu pada standar ASTM D 790-03 yaitu:

$$
\sigma_{b}=\frac{3 P L}{2 b d^{2}}
$$

Dimana; $\sigma_{\mathrm{b}}$ adalah tegangan pada tengah-tengah batang (MPa), $\mathrm{P}$ adalah pembebanan bending maksimum $(\mathrm{N}), \mathrm{L}$ adalah jarak penampang spesimen uji $(\mathrm{mm})$, b adalah lebar spesimenl uji $(\mathrm{mm})$ dan d adalah tebal spesimenl uji (mm).

Regangan bending adalah perubahan bagian nilai panjang sebuah elemen pada permukaan terluar dari spesimen di tengah-tengah span dimana tegangan maksimum terjadi. Regangan maksimum ditengah batang dihitung dengan persamaan:

$$
\varepsilon_{b}=\frac{6 D d}{L^{2}}
$$

Dimana; $\varepsilon_{\mathrm{b}}$ adalah regangan maksimum, $\mathrm{D}$ adalah defleksi maksimum di tengah-tengah bentang spesimen $(\mathrm{mm}), \mathrm{L}$ adalah jarak tumpuan $(\mathrm{mm}), \mathrm{d}$ adalah tebal batang $(\mathrm{mm})$.

\section{Hasil dan Pembahasan}

3.1. Hasil pengujian tarik komposit
Tabel 1. Rata-rata hasil uji tarik

\begin{tabular}{|c|r|r|r|}
\hline $\begin{array}{c}\text { Fraksi } \\
\text { serat }\end{array}$ & $\varepsilon(\%)$ & $\sigma(M p a)$ & E (Mpa) \\
\hline $0 \%$ & 0.42 & 8.59 & 2045.24 \\
\hline $10 \%$ & 0.27 & 9.43 & 3492.59 \\
\hline $15 \%$ & 0.33 & 10.60 & 3212.12 \\
\hline $20 \%$ & 0.36 & 12.18 & 3383.33 \\
\hline
\end{tabular}

Pengujian material komposit yang telah dilaksanakan dengan masing-masing perlakuan dilakukan pengulangan 3 kali. Kekuatan tarik komposit dengan penguat serat jelatang meningkat di bandingkan dengan resin tanpa serat. Kekuatan tarik tertinggi terjadi pada komposit yang diperkuat serat $20 \%$, yaitu sebesar $12,18 \mathrm{MPa}$, sedangkan kekuatan tarik resin adalah 8,59 $\mathrm{MPa}$. Hasi pengujian kekuatan tarik komposit dapat dilihat pada gambar 4 .

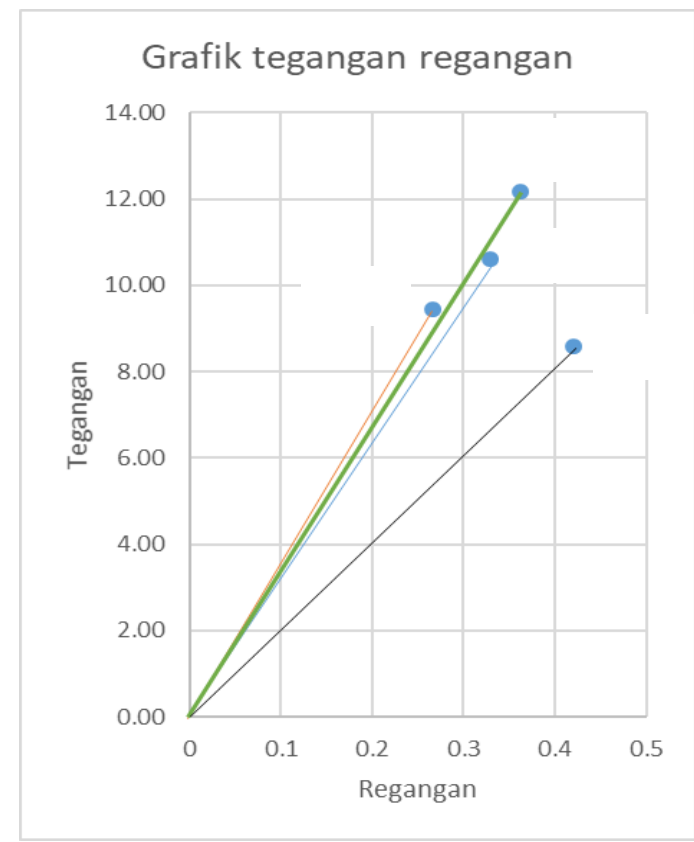

Gambar 4. Grafik tegangan regangan tarik komposit berpenguat serat jelatang

\subsection{Pembahasan uji tarik komposit}

Hasil penelitian Sri Rahayu kekuatan tarik epoksi ditambah hardener tanpa serat penguat adalah 16,49 - 57,93 MPa[4]. Sedangkan pada penelitian ini hasil uji tarik epoksi tanpa serat jelatang adalah 8,59 MPa, ini menandakan bahwa kualitas epoksi yang dipakai pada penelitian ini rendah, atau waktu produksi epoksi sudah lama sehingga kekuatan tariknya menurun.

Penelitian serat mendong sebagai penguat pada matriks Epoksi BAKELITE EPR 174 dengan orientasi serat $0^{0}$ kekuatan tarik $26,60 \mathrm{MPa}$, sedangkan pada $90^{\circ}$ kekuatan tarik $0,63 \mathrm{MPa}[5]$. Arah orientasi serat sangat pengaruh terhadap kekuatan tarik komposit, serat jelatang arah orientasinya acak kekuatan tarik tertinggi pada fraksi serat $20 \%$ yaitu $12,18 \mathrm{MPa}$.

Jika dibandingkan dengan matrik murni, semua komposit diperkuat serat jelatang memiliki kekuatan tarik lebih tinggi dibandingkan dengan matrik murni. Komposit yang diperkuat serat jelatang kekuatan tarik meningkat berbanding lurus dengan bertambahnya fraksi volume serat. 


\subsection{Hasil Uji Kekuatan Lentur}

Hasil pengujian kekuatan lentur dapat dilihat pada gambar 5 dan 6 sebagai berikut:

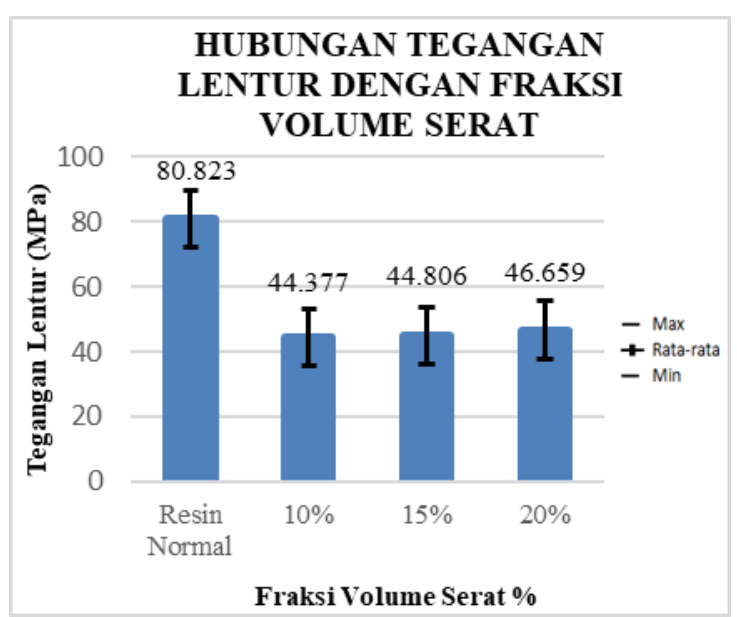

Gambar 5. Diagram tegangan lentur

Nilai rata-rata kekuatan lentur dari 3 variasi komposisi penguat dan pengikat pada komposit resin epoksi berpenguat jelatang. Pada bahan resin epoksi tanpa material serat (penguat $0 \%$ ) diperoleh kekuatan lentur memiliki nilai sebesar 80,823 Mpa. Kekuatan lentur komposit dengan penguat $10 \%$ yaitu $44,377 \mathrm{MPa}$ dan meningkat seiring dengan pertambahan komposisi serat $15 \%$ yaitu $44,806 \mathrm{MPa}$ serta $20 \%$ yaitu 46,659 MPa.

Penurunan kekuatan komposit berpenguat dibandingkan dengan epoksi murni dapat disebabkan oleh ikatan serat dan matrik tidak kuat, tetapi ketika ada penambahan fraksi volume antara penguat (serat) dan pengikat (matriks) menyebabkan distribusi dan transfer beban yang dihasilkan meningkat seiring dengan kemampuan serat untuk menstrasfer beban secara baik. Akan tetapi nilai peningkatan kekuatan lentur tidak melebihi dari nilai kekuatan lentur epoksi murni (resin epoksi tanpa penguat) dikarenakan komposisi tanpa penguat mampu mendistribusikan beban secara maksimal.

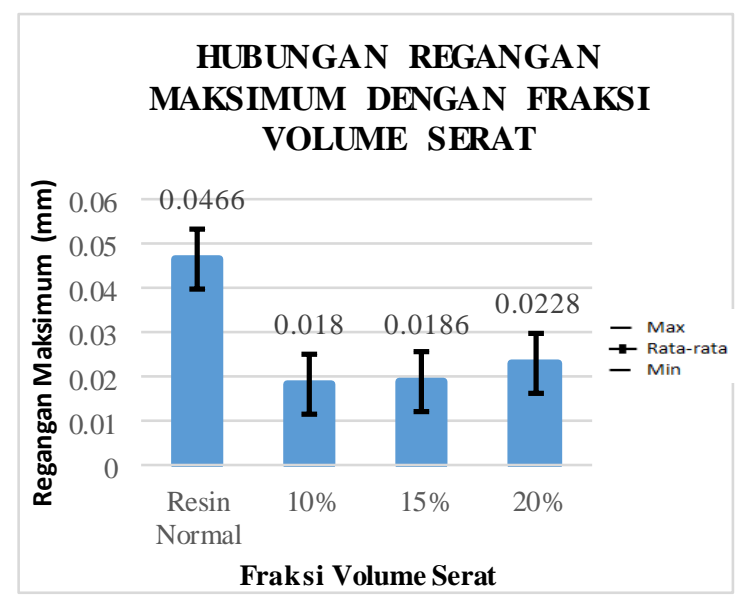

Gambar 6. Diagram regangan lentur

Data hasil rata-rata perhitungan regangan lentur didapatkan hasil tertinggi pada resin murni (tanpa penguat serat) yaitu $0,0466 \mathrm{~mm}$. Pada material komposit nilai regangan lentur pada fraksi volume serat $10 \%$ dengan nilai $0,018 \mathrm{~mm}$, pada fraksi volume serat $15 \%$ nilai sebesar $0,0186 \mathrm{~mm}$ dan pada fraksi volume serat $20 \%$ nilai sebesar $0,0228 \mathrm{~mm}$. Secara garis besar dengan penambahan fraksi volume serat regangan lentur meningkat, tetapi peningkatan yang terjadi tidak terlalu signifikan dan masih dibawah komposisi fraksi volume serat $0 \%$ (resin normal).

Beberapa penelitian lain tentang serat penguat komposit banyak diteliti, serat penguat komposit dari ampas tebu[6], serat rami yang diaplikasikan pada thermal shock[7] dan serat pandan wangi pada komposit polyester[8].

\subsection{Hasil SEM}

Pada uji SEM sampel diambil dari sampel yang telah patah akibat beban lentur, bagian material tersebut dipotong ke arah tebal dengan ukuran panjang $1 \mathrm{~cm}$ dan lebar $1 \mathrm{~cm}$. Preparasi sampel dilakukan dengan dilapisi emas tipis lalu dilakukan uji SEM. Pengujian SEM dilaksanakan untuk menunjang dalam menganalisa kegagalan yang terjadi pada material komposit akibat pebebanan. Hasil foto SEM komposit dengan penguat $0 \%, 10 \%, 15 \%$, dan $20 \%$ dapat dilihat pada gambar 7, 8, 9 dan 10 sebagai berikut:

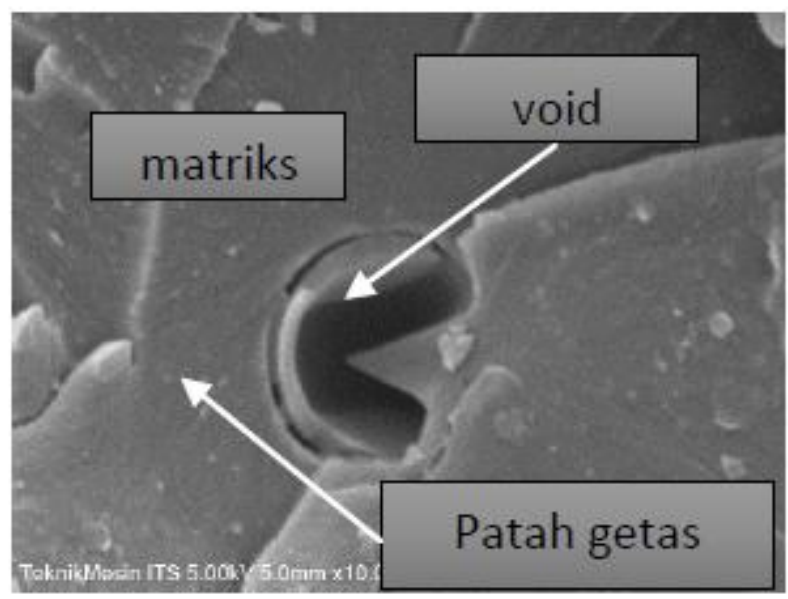

Gambar 7. Patahan epoksi tanpa serat

Pada hasil pengamatan SEM pada komposisi 0\% (resin epoksi tanpa penguat) dapat dilihat beberapa faktor penyebab kegagalan material antara lain adanya campuran yang kurang merata antara resin dan hardener serta porositas yang mengakibatkan material tidak bisa menerima beban secara maksimal, dikarenakan porositas tersebut dapat menjadi salah satu faktor terjadinya patahan sehingga beban yang diterima tidak dapat ditransfer ke semua bagian. 


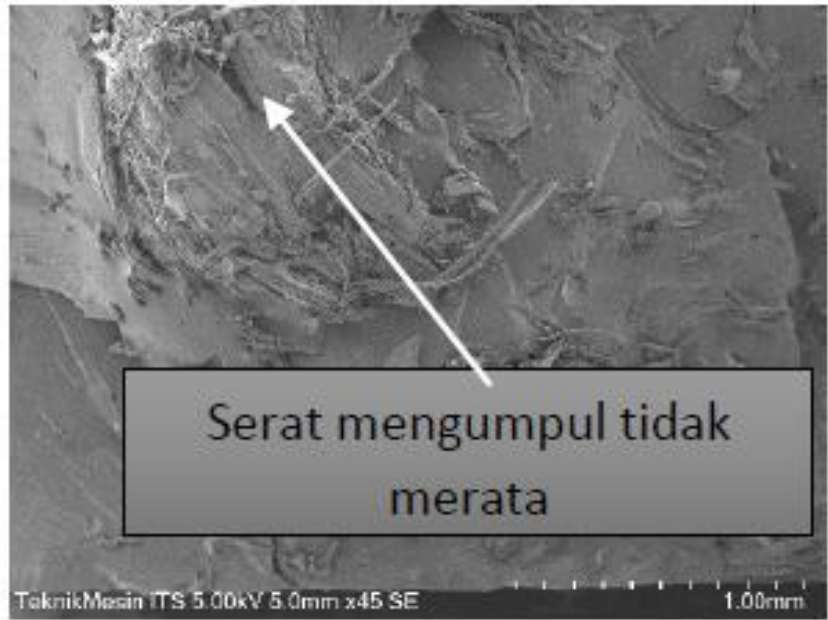

Gambar 8. Patahan komposit $10 \%$ serat

Berdasarkan hasil pengamatan komposit dengan perbandingan $10 \%$ serat didapatkan bahwa kegagalan yang terjadi diakibatkan beberapa faktor antara lain jumlah fraksi volume penguat yang sedikit serta adanya serat yang mengelompok (tidak merata) yang terdapat pada beberapa bagian komposit yang mengakibatkan beban tidak terdistribusi secara merata.

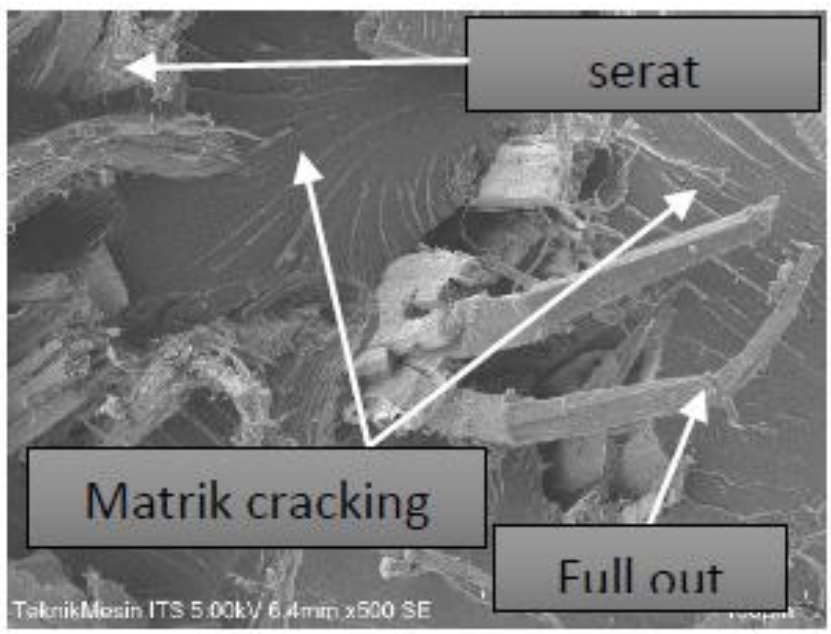

Gambar 9. Patahan komposit $15 \%$ serat

Komposit $15 \%$ serat terlihat jumlah serat tersebar secara merata dan terikat dengan baik akan tetapi di beberapa bagian juga terdapat serat dan matriks yang tidak terikat dengan baik, sehingga memungkinkan terjadinya pull out atau lepasnya ikatan serat dari matriksnya, sehingga dapat mempengaruhi kemampuan menahan beban dari material komposit tersebut.

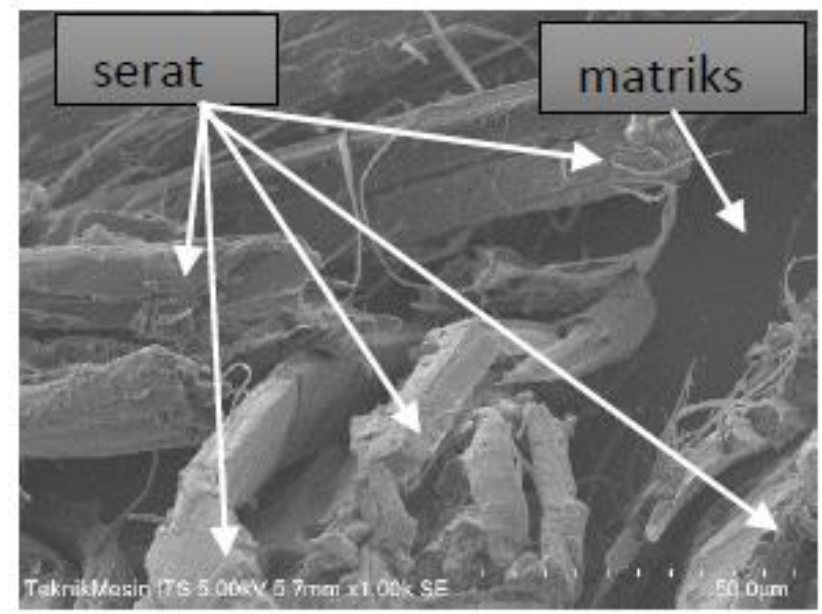

Gambar 10. Patahan komposit 20\% serat

Gambar 10, memperlihatkan jumlah serat yang terdapat pada komposit semakin meningkat dan terikat secara baik dengan resin epoksi sehingga beban yang diterima dapat di distribusikan ke semua bagian secara merata, akan tetapi masih terdapat sedikit porositas yang dapat mengurangi kekuatan yang dapat diterima material tersebut. Hal ini dipengaruhi proses pembuatan yang masih secara manual (hand lay up) sehingga material yang dihasilkan kekuatannya kurang maksimal.

\section{Simpulan}

Material komposit yang diproduksi dengan penguat serat jelatang pada fraksi volume 10\%, 15\% dan $20 \%$ serat mempengaruhi kekuatan tarik. Fraksi volume serat bertambah kekuatan tarik juga meningkat. Kekuatan tarik terbesar pada fraksi volume serat $20 \%$ dengan nilai $12,18 \mathrm{MPa}$.

Kekuatan lentur bahan komposit resin epoksi berpenguat serat jelatang, didapatkan hasil yang terbesar pada material dengan perbandingan $20 \%$ serat dengan hasil nilai kekuatan lentur sebesar 46.66 $\mathrm{MPa}$ dan nilai regangan lentur sebesar $0.023 \mathrm{~mm}$. Kekuatan lentur terkecil pada komposisi $10 \%$ sebesar $44.38 \mathrm{MPa}$ dan $0.018 \mathrm{~mm}$ untuk regangan.

\section{Daftar Pustaka}

[1] Bodros E. \& Baley C., Study of the tensile properties of stinging nettle fibres (Urtica dioica), Materials Letters 62, 2143-2145, 2008

[2] Fischer H., Werwein E. and Graupner N., Nettle fibre (Urtica dioica L.) reinforced poly(lactic acid): A first approach, Journal of Composite Materials 46(24), 3077-3087, 2012

[3] I G P Agus Suryawan, N P G Suardana, I N Suprapta Winaya, I W Budiarsa Suyasa, T G Tirta Nindhia, Potential of Stinging Nettle (Urtica Dioica L.) Fibers Reienforced Green Composite Materials : A Review, IOP Conference Series: Materials Science and Engineering, 201, 2017

[4] Sri Rahayu dan Mabe Siahaan, Karakteristik raw material epoxy resin tipe BQTN-EX 157 yang digunakan sebagai matrik pada komposit, Teknologi Dirgantara Vol. 15 No. 2, 151 -160, 2017 
[5] Lies Banowati, Wisnu Adi Prasetyo, Devi M Gunara, Analisis Perbandingan Kekuatan Tarik Orientasi Unidirectional $0^{\circ}$ Dan $90^{\circ}$ Pada Struktur Komposit Serat Mendong Dengan Menggunakan Epoksi Bakelite Epr 174, Infomatek Volume 19 Nomor 2, 57 - 64, Desember 2017

[6] Agus Triono, Pemanfaatan Ampas Tebu sebagai Reinforcement pada Pembuatan Rem Komposit Berbahan Alami, Jurnal Energi Dan Manufaktur Vol. 7 No. 1, April 2015

[7] Rozi Saferi, Hendery Dahlan, Mulyadi Bur, Pengaruh Thermal Shock Terhadap Kekuatan Tarik dan Bending Komposit Resin Berpenguat Serat Rami, Jurnal Energi dan Manufaktur Vol. 8, No. 2, Oktober 2015

[8] IGNK. Yudhyadi dan Nasmi Herlina Sari, Analisa Kekuatan Impact Komposit Polyester Diperkuat Serat Pandan Wangi dengan Pengisi Serbuk Gergaji Kayu, Jurnal Energi Dan Manufaktur, Vol 6 No 2, Oktober 2013

[9] ASTM D3039/D3039M, Standart Test Method for Tensile Properties of Polymer Matrix Composite Materials, Annual Book of ASTM Standards, United States: ASTM International, 2002

[10] ASTM D790-03, Standart Test Methode for Flexure Sifates of Plastic, Annual Book of ASTM Standards, United States: ASTM International, 1998 